\title{
The Effects of Brainstorming and Predicting as Schema Activation Strategies on the Algerian EFL Students' Reading Comprehension: An Experimental Study at the Department of English, Blida 2 University, Algeria
}

\author{
Abla Benbellal ${ }^{1}$ \\ ${ }^{1}$ Department of English, Faculty of Foreign Languages, Algiers 2 University, Algeria \\ Correspondence: Abla Benbellal, Algiers 2 University, Algeria. \\ Email: ablaben460@gmail.com
}

doi: 10.23918/ijsses.v7i2p62

\begin{abstract}
This research aims at investigating the effects of schema activation, using brainstorming and predicting, on students' reading comprehension at the English department, Blida 2 University, Algeria. To this end, an experimental research design was adopted where two data collection instruments were used: a students' questionnaire to elicit students' attitudes towards reading in English, their difficulties in reading comprehension and use of brainstorming and predicting as schema activation strategies, and an experiment in which two experimental groups were taught how to activate their schemata prior to reading through brainstorming and predicting strategies. The results of the study demonstrated that an interactive reading approach based on activating students' schemata through brainstorming and predicting had significant effects on the process of comprehending texts and increased students' motivation to read.
\end{abstract}

Keywords: Schema Activation, Brainstorming, Predicting, Reading Comprehension EFL Students

\section{Introduction}

Reading is one of the most important skills in second and foreign language learning (Grabe \& Stoller, 2001) as it helps EFL learners master other language skills. For example, a learner who wants to be a good writer, he needs to be a good reader. Moreover, EFL learners need to master reading so as to communicate and receive new information. This information is usually transferred in written materials such as books, articles and newspapers. Thus, in order to better understand these written materials and construct the meaning of texts, learners have to read effectively by using appropriate reading strategies that are considered to be the keys that allow students to monitor and improve their comprehension which is the essence of the reading act (Teele 2004 as cited in Küçükoğlu, 2012).

However, despite its importance, reading is one of "the most challenging areas in the education system." (Küçükoğlu, 2012, p.709). We have observed that students, at Blida 2 University, Department of English, encounter difficulties in foreign language reading mainly because they do not give reading strategies the importance they deserve. Most of them end up being unable to comprehend the meaning conveyed in the text as a whole. This claim is based on the bad scores they got in the reading exam. According to Carrell \& Eisterhold (1983), one of the reasons that lead to reading comprehension failure is the mismatch between the background anticipated by the writer and the possessed knowledge of the reader. This mismatch breaks down learners' comprehension that is claimed to be the essence of reading for foreign language learners. In addition, students usually read without using strategies. Therefore, they perform inadequate responses 
in the reading tasks. By taking into consideration these issues, it is necessary for students at Blida 2 University, Department of English to be equipped with effective reading strategies in order to improve their reading comprehension.

Research showed that assisting learners to bring what they know about a given topic to the text they are reading is crucial for effective comprehension. This is referred to as activating schema (Carrell \& Eisterhold, 1983). Activating schema may not lead to the same schema anticipated by the writer, but it leads EFL readers to relate their existing ideas and past experiences with what is appearing in the text in order to achieve comprehension (Anderson \& Pearson, 1988). That is why, we think that in order to develop our students' reading comprehension abilities, we need to develop our teaching of reading through raising students' awareness of the necessity of activating their schemata prior to reading and having them practice using two schema activation strategies, namely brainstorming and predicting, to help students get the meaning of what is written and achieve better understanding of the text.

\section{Review of the Related Literature 2.1. Definition of Reading}

Reading is the process of looking at words and symbols, extracting their meaning and storing them for later use. However, given the complex nature of this skill (Dorn \& Soffos, 2005) that requires the reader to use various processes in order to construct meaning, many definitions regarding its nature have been provided. For example, Goodman's description of reading stresses the importance of the reader's mental abilities, psychological state and socio-cultural environment. For him, "reading is a psycholinguistic guessing game. It involves an interaction between thoughts and language." (Goodman, 1976, p.127). What is meant by guessing from Goodman's description is that reading goes beyond just identifying sounds carried out by letters and symbols. That is, the reader is not a passive decoder of the text's words but rather s/he interacts with the text trying to predict its meaning based on his prior knowledge about the topic of that text (Carrell \& Eisterhold, 1983). Likewise, Probst (1987) claims that the reader's prior knowledge is the basis upon which understanding the text is built. According to her, reading is a challenging process that requires a variety of necessary elements to understand the meaning of the text. In her words, the reading act is defined as: "an event involving a particular text, happening at a particular time, under particular circumstances, in a particular social and cultural setting, and as part of the ongoing life of the individual and the group." (Cited in Wyse \& Goswami, 2012, p.388).

Another definition that puts the text in its social context and considers the reader's individuality and contribution to the text is that of Lundahl (1998) who believes that constructing the meaning of the text is "an active process" that requires the reader to see the text from different angles based on his/her previously stored knowledge (Cited in Alqahtani \& Aljidy, 2011). This definition stresses the social nature of the reading process in which the readers, according to (Wallace 2003), are not "private individuals" but rather members of a discourse community who interact with texts which are "social and cultural artifacts" (p.15). 


\subsection{Schema as a Concept}

Schema is defined as the cognitive base which the reader draws upon to match new incoming information with prior information stored in memory, thereby deriving meaning from what is read (Rumelhart, 1980; Dechant, 2013). The term schema was firstly introduced by Bartlett (1932) whose view was based on the assumption that the written text is not the source of meaning, rather it provides the reader with cues that will help him activate his prior knowledge that plays a significant role in extracting the meaning of a given text. Bartlett defines schema as "an active organization of past reactions or of past experiences which must always be supposed to be operating in any well-adapted organic response" (1932, p.201). That is, schema is a mental representation of past experiences and what we already learnt and stored in our memory that will help us cope with new experiences. Likewise, Anderson (1985) views schema as an organized knowledge of the world. Readers make use of their schema when they try to relate what they already know about a topic to what is appearing in a text; therefore, they rely on their background knowledge and world experiences when they try to comprehend a given text. In Anderson's words, "comprehension occurs when a reader activates or constructs a schema that provides a framework for the message delivered in the text" (cited in McCormack \& Pasquarelli, 2009, p.94).

\subsection{Schema Activation Strategies}

The reader's schema can be activated through using different strategies that help learners' minds get ready for active interaction with a given text. This section sheds light on the two strategies which form the major focus of our study: brainstorming and predicting.

\subsubsection{Brainstorming}

Using brainstorming as a reading strategy, students are allowed to work cooperatively to ask questions and have a long list of ideas about a particular topic. Readers bring all that is in their brains which they may think is related to the topic under discussion. Brainstorming is defined by Osborn (1953) as "an organized way to allow the mind to produce ideas without getting bogged down in trying to judge the value of those ideas at the same time." (Cited in Kirk \& Sprecklmeyer, 1993, p.85). Through brainstorming, students become aware of what they know about a particular topic before reading. In this regard, Feather (2004) claims that "brainstorming enhances the activation of the reader's schema globally; so that they will know in advance about the ideas, vocabulary, culture, grammatical features and genre structures which are most probably met in the text to be read." (Cited in Ghabanchi \& Behrooznia, 2014, p.514). Furthermore, this strategy plays a significant role in stimulating readers' motivation. That is, when teachers provide students with opportunities to express themselves freely and interact with each other while brainstorming ideas, they increase students' motivation and interest in reading (Ajideh, 2006).

\subsubsection{Predicting}

Predicting is a reading strategy that requires readers to make formal guesses about what will happen in the text based on clues from the text they attempt to read such as the title, headings, text structure, knowledge about the author and the vocabulary used. That is, predicting is "an intellectual or emotional extension of one's knowledge and experience into the unknown, under the constraints of specific conditions or actions." 
(Herber, 1978 as cited in Olshavsky \& Kletzing, 1979, p. 512). As a cognitive reading strategy, predicting plays a significant role in activating readers' schemata and thus helping them read with more understanding (Gillet \& Temple, 1982 as cited in Kelly \& Clausen-Grace, 2007). In other words, "the value of this strategy allows the reader to activate schema, promote interest, and provide links between the known and the unknown" (Paris et al., 1991. as cited in Wood, 2008, p.19).

\section{Purpose of the Study and the Research Questions}

The aim of this study is to investigate the effects of activating schema on first year students' reading comprehension. It also aims at raising teachers' awareness on the importance of activating students' prior knowledge before reading in order to help them construct meaning and better understand texts.

Hence, this study addressed the following research questions:

- What are the effects of brainstorming on first year students' performance in reading comprehension?

- What are the effects of predicting on first year students' performance in reading comprehension?

\section{Methods and Materials}

\subsection{Participants}

A random sample of forty-seven (47) students, from the Department of English at Blida 2 University, participated in our study. Their age ranged from 18 to 21 . The sample was divided into three groups; 16 students in each: two experimental groups: group 'A' (brainstorming), group 'B' (predicting) and one control group (group ' $\mathrm{C}$ ').

\subsection{Data Collection Instruments 4.2.1. Students' Questionnaire}

The students' questionnaire was designed to elicit students' attitudes towards reading in English, their difficulties and use of different reading strategies particularly activating schema. The questionnaire consists of 19 items. It is divided into three sections where the questions range from general to specific. The first section, which is entitled 'reading habits and attitudes' (Qs 1, 2, 3, 4 \& 5), aims at getting information about attitudes towards the importance of FL reading and the different types of texts known by students. Section two, which is entitled 'reading difficulties and strategies' awareness'(Qs 6, 7,8,9,10 \& 11), aims at eliciting information about students' difficulties in understanding texts in English and use of reading strategies. The last section, which is entitled 'activating schema and reading comprehension' (Qs 12,13,14,15,16, 17, 18 \& 19), tends to obtain information about students' opinions towards making the link between the new input presented in the text and their previously stored knowledge as well as their use of brainstorming and predicting before reading a given text. 


\subsubsection{The Experiment: Description of Tasks \\ 4.2.2.1. The Pre-Test}

Before the treatment took place, the participants had a reading comprehension test. The test consists of a reading passage followed by ten multiple choice questions; each question has four alternatives. The test was administered in order to measure students' comprehension level.

\subsubsection{The Treatment}

The treatment lasted for 5 weeks with an average of 2 sessions per week. That is, a total of 10 sessions; each session lasted one hour and a half. Students were divided into three groups: groups 'A' (brainstorming) and 'B' (predicting) are the experimental groups while the third group ' $\mathrm{C}$ ' was taken as the control group. Each group included 16 students.

\subsubsection{The Post-Test}

The text that was given to group ' $A$ ' (brainstorming group) after the treatment was followed by 3 multiple choice questions, 7 true or false statements, and 3 short answer questions.

Regarding group 'B' (predicting group), after the treatment, students were asked to read two texts. Both texts were followed by a set of questions where students were asked, before reading the passage, to predict its content and then read it to check their predictions.

\subsection{Data Collection Procedures}

\subsubsection{Students' Questionnaire}

The administration of students' questionnaire took place in December 2014. Students answered the questionnaire during regular sessions of study skills. The researcher was present to offer help when necessary. The meaning of the term 'schema' was explained and students were informed that their answers would remain anonymous.

\subsubsection{The Experiment}

\subsubsection{The Pre-Test}

In a regular session, students were asked to read a text and select the appropriate option to answer each question. Students read the passage silently for 12 minutes; then, they answered the questions that followed the reading passage. It took them 20 minutes to answer the comprehension questions.

\subsubsection{The Treatment A. Brainstorming Sessions}

Students of group 'A' were taught brainstorming as a schema activation strategy. The teacher needed only three sessions to teach them this strategy. This is due to the fact that students were familiar with this strategy in the module of writing. Thus, no difficulty was encountered in teaching brainstorming as a reading strategy. 
After introducing the strategy, students were required to practice brainstorming as a schema activation strategy. Before reading, only the topic of the text was given to students as they were asked to discuss and write down everything they know about that topic. After discussing the topic, students were given the targeted text to read silently. After the allotted time was over, the teacher gave her students the questions and took the texts away. Hence, students did not have the opportunity to copy from the text, but rather they were asked to read the questions and answer them relying on their prior knowledge and what they had discussed with their peers while brainstorming.

\section{B. Predicting Sessions}

Students of group 'B' were taught predicting as a reading strategy to activate their schemata. Teaching this strategy was a bit difficult as compared to brainstorming since the students were not familiar with predicting. Thus, the teacher needed 7 sessions- one hour and a half for each- to teach students how to make predictions. The teacher explained to the students the importance of making predictions in helping them make connections between new information and past experiences. Next, students were introduced to the different components of this strategy including the title, the pictures, the readers' prior knowledge about the topic and the text structure as well.

After teaching the different components of predicting, students were given opportunities to practice using those components to predict the content of the text before reading it. In each exercise, students were asked to read part of the text and then stop to answer a set of questions that would help them make predictions about its content. These questions are:

- Above are the title, subtitle, and the author's introduction from an article on smartphone addiction. On the basis of these, what main points, you predict, are covered in the article?

- What words/phrases make you predict that?

- What do you know about the type of the text?

- What do you expect to read next?

- Were your predictions confirmed?

Students of group ' $\mathrm{C}$ ' (control group) took only reading comprehension pre-test and post-test without any treatment.

\subsubsection{The Post-Test}

In order to check the extent to which students reading performance, in both groups, has improved after the training, a post-test was administered, as a final step in the experiment.

In group ' $A$ ' (brainstorming), after giving them the title of the text, students started discussing and brainstorming ideas as they did in the training sessions. Afterwards, students read the text and answered the questions based on their prior knowledge and discussions with their peers while brainstorming. It took them 40 minutes to do the task. 
As they did in the training sessions, the students in group ' $\mathrm{B}$ ' (predicting) were asked to read part of the text and then answer a set of questions, taking into consideration the components discussed above (See 2.2.3.2.), that guide them to predict the content of the next part. It took them 45 minutes to do the task.

Regarding the control group, students read the same texts but without using brainstorming and predicting to activate their schemata. Afterwards, the answer sheets were collected for correction, analysis, and comparison of the results with the ones of the pre-test.

\section{Results}

\subsection{Results of the Students' Questionnaire}

The results obtained from the students' questionnaire are reported with no discussion or comment on them. In this section, only the results of the items that would help us answer the research questions are reported.

\section{a. Reading Difficulties}

This section aimed at eliciting information about reasons behind students' difficulties in reading texts (Qs $6 \& 7$ ): the results of the sixth question show that more than half of students $(68,09 \%)$ have difficulties in reading texts in English. As shown in Table 1, when asked about reasons behind their difficulties in reading (Q7), 40, 42\% said that a text is difficult when it has many unfamiliar/unknown words. $14,89 \%$ stated that a text is difficult when it is about a topic they know nothing about. 4, 26\% said that when they had no idea about the purpose of reading, the text became difficult to understand. $8,51 \%$ claimed that a text is difficult when it is of a different culture. $31,91 \%$ gave no answer.

Table 1: Reasons behind Text Difficulties

\begin{tabular}{|l|c|c|}
\hline \multicolumn{1}{|c|}{ Options } & $\begin{array}{c}\text { Participants } \\
(\mathrm{N})\end{array}$ & Percentages (\%) \\
\hline a. The text has many unfamiliar/ unknown words. & 19 & 40,42 \\
\hline b. The text is about a topic you know nothing about & 7 & 14,89 \\
\hline c. You don't have any idea about the purpose of reading & 2 & 4,26 \\
\hline d. When the text is of a different culture & 4 & 8,51 \\
\hline No answer & 15 & 31,91 \\
\hline Total & 47 & 100 \\
\hline
\end{tabular}

b. Activating Schema and Reading Comprehension

This section aimed at eliciting information about:

b.1. Students' opinions towards making the link between new input presented in the text and their previously stored knowledge (Qs 12, 15, 17, 18 \& 19):

As demonstrated in Tables 2 and 3, the results of questions 17, 18 and 19 show that more than half of students (Qs 17 \& 18: 87, 24\%; Q19: 74,46\%) stated that their prior knowledge played a significant role in helping them better comprehend a given text. 
Table 2: Prior Knowledge and Understanding the Text

\begin{tabular}{|c|c|c|}
\hline Options & Participants (N) & Percentages (\%) \\
\hline Yes & 41 & 87,24 \\
\hline No & 5 & 10,64 \\
\hline No answer & 1 & 2,12 \\
\hline Total & 47 & 100 \\
\hline
\end{tabular}

Table 3: Why Prior Knowledge Is Important

\begin{tabular}{|c|c|c|}
\hline Options & Participants (N) & $\begin{array}{c}\text { Percentages } \\
(\%)\end{array}$ \\
\hline $\begin{array}{l}\text { a- Recalling previously stored information is } \\
\text { important to comprehend the text because they } \\
\text { already have an idea about the topic which makes } \\
\text { the text easy and avoid misunderstanding. }\end{array}$ & 35 & 74,46 \\
\hline b- No answer & & \\
\hline Total & 12 & 25,54 \\
\hline
\end{tabular}

b.2. Students' use of brainstorming and predicting before reading a given text (Qs 13, 14 \& 16):

When the students were asked about the use of brainstorming (Q13), 38,3\% said that, before reading a given text, they 'always' discuss the text's topic with their friends and write down all what they know about it (See Table 4). When they were asked whether they try to make guesses about the content of the text before reading it (Qs 14 \& 16), the answer of the majority of students (Q14: 80,85\%; Q16: 87,24\%) was 'Yes' to both questions (See Table 5).

Table 4: Brainstorming Ideas

\begin{tabular}{|c|c|c|}
\hline Options & Participants (N) & Percentages (\%) \\
\hline Rarely & 16 & 34,05 \\
\hline Sometimes & 13 & 27,65 \\
\hline Always & 18 & 38,3 \\
\hline Total & 47 & 100 \\
\hline
\end{tabular}

Table 5: Inferring Events

\begin{tabular}{|c|c|c|}
\hline Options & Participants (N) & $\%$ \\
\hline Yes & 41 & 87,24 \\
\hline No & 3 & 6,38 \\
\hline No answer & 3 & 6,38 \\
\hline Total & 47 & 100 \\
\hline
\end{tabular}




\subsection{Results of the Experiment 5.2.1. Results of the Pre-Test}

The scores obtained by the students in the pre-test are reported in Table 6 . The scores are arranged from the highest to the lowest score.

Table 6: The Experimental Groups (A \& B) and the Control Group Scores in the Pre-test

\begin{tabular}{|c|c|c|c|c|c|c|}
\hline \multirow{5}{*}{$\begin{array}{l}\text { Pre- } \\
\text { test }\end{array}$} & \multicolumn{3}{|c|}{ Experimental Groups (A \& B) } & \multicolumn{3}{|c|}{ Control Group } \\
\hline & $\begin{array}{c}\text { Scores (out of } \\
20 \text { ) }\end{array}$ & $\begin{array}{c}\text { Frequenc } \\
\mathrm{y}\end{array}$ & Percentages & $\begin{array}{l}\text { Scores (out of } \\
20 \text { ) }\end{array}$ & $\begin{array}{c}\text { Frequenc } \\
\mathrm{y}\end{array}$ & $\begin{array}{c}\text { Percentage } \\
\text { s }\end{array}$ \\
\hline & 00 & 2 & $6,89 \%$ & 00 & 1 & $6,66 \%$ \\
\hline & 02 & 1 & $3,44 \%$ & 02 & 2 & $13,33 \%$ \\
\hline & 04 & 10 & $34,48 \%$ & 04 & 4 & $26,66 \%$ \\
\hline & 06 & 8 & $27,58 \%$ & 06 & 5 & $33,33 \%$ \\
\hline & 08 & 7 & $24,13 \%$ & 08 & 2 & $13,33 \%$ \\
\hline & 10 & 1 & $3,44 \%$ & 10 & 2 & $13,33 \%$ \\
\hline & Average: 5, 37 & Total: 29 & $\begin{array}{c}\text { Total } \\
\text { Percentage: } \\
100 \%\end{array}$ & Average: 5,73 & Total: 15 & $\begin{array}{c}\text { Total } \\
\text { Percentage: } \\
100 \%\end{array}$ \\
\hline
\end{tabular}

As shown in the table, the experimental group scored 5, 37 out of 20 points while the control group scored 5,73. Comparing the averages of the experimental groups and the control group, there seems to be no significant difference in their performance in the pre-test. In the experimental group, we notice that the lowest mark in the pre-test is 00 out of 20 and it was obtained by 6,89\% of participants who were not able to answer any of the ten questions in the reading passage while the highest mark is 10 out of 20, and only one student (3.44\%) got it. The highest rate $(34,48 \%)$ was obtained by those who got 4 out of 20 . Seven students $(24,13 \%)$ who were successful in providing 4 correct answers got 8 out of 20. Eight students $(27,5 \%)$ were able to answer only 3 questions and got 6 out of 20 . One student $(3,44 \%)$ provided only one correct answer out of ten and got 2 out of 20 .

Regarding the control group, nearly the same results were noted. The lowest mark is 00 out of 20 and $6,66 \%$ of participants got it while the highest mark is 10 out of 20 , and $(13,3 \%)$ of students were able to answer 5 questions out of 10 . The highest rate 33,33\% is obtained by those who got 6 out of 20. $(26,66 \%)$ of students got 4 out of 20 . Two students $(13,33 \%)$ were able to answer only one question out of ten. $13,33 \%$ of students provided 4 correct answers and got 8 out of 20 . 


\subsubsection{Results of the Post-Test}

\subsubsection{Results of the Brainstorming Test}

The scores obtained, by both experimental and control groups, in the brainstorming test are presented in Table 7. They are arranged from the lowest to the highest score. The scores are also presented through a histogram to make it easy for the reader to notice the difference between the scores obtained by the experimental group (A) and the control group (C) in the test (See Figure 1). All the scores obtained by students in the experimental group (A) were above the average. In more detail, we notice that the lowest mark in the post-test is 11 and it was obtained by $14.28 \%$ of students while the highest mark is 16.5 and only one student $(7.14 \%)$ got it. The highest rate is (14.28\%). It represents those students who got the marks: $11,11.5,12,12.5,14,14.5,15$.

Table 7: Brainstorming Test Results

\begin{tabular}{|c|c|c|c|c|c|c|}
\hline & Experi & ntal Grou & & $\mathrm{Co}$ & rol Group & \\
\hline & $\begin{array}{l}\text { Scores (out of } \\
20 \text { ) }\end{array}$ & $\begin{array}{c}\text { Frequenc } \\
\mathrm{y}\end{array}$ & Percentages & $\begin{array}{l}\text { Scores (out } \\
\text { of 20) }\end{array}$ & $\begin{array}{c}\text { Frequenc } \\
\mathrm{y}\end{array}$ & Percentages \\
\hline & 11 & 2 & $14.28 \%$ & 04 & 1 & $5,88 \%$ \\
\hline & 12 & 1 & $7,14 \%$ & 4.5 & 1 & $5,88 \%$ \\
\hline & 12.5 & 2 & $14,28 \%$ & 5.5 & 1 & $5,88 \%$ \\
\hline Post- & 13 & 1 & $7,14 \%$ & 06 & 1 & $5,88 \%$ \\
\hline & 14 & 2 & $14,28 \%$ & 7.5 & 4 & $23,52 \%$ \\
\hline & 14.5 & 2 & $14,28 \%$ & 08 & 1 & $5,88 \%$ \\
\hline & 15 & 2 & $14,28 \%$ & 8.5 & 1 & $5,88 \%$ \\
\hline & 15.5 & 1 & $7,14 \%$ & 09 & 2 & $11,76 \%$ \\
\hline & 16.5 & 1 & $7,14 \%$ & 10.5 & 1 & $5,88 \%$ \\
\hline & & & & 11 & 1 & $5,88 \%$ \\
\hline & & & & 12.5 & 1 & $5,88 \%$ \\
\hline & & & & 13 & 1 & $5,88 \%$ \\
\hline & & & & 13.5 & 1 & $5,88 \%$ \\
\hline & Average:13.64 & Total:14 & $\begin{array}{c}\text { Total } \\
\text { Percentage: } \\
100 \%\end{array}$ & Average: 7.9 & Total: 17 & $\begin{array}{c}\text { Total } \\
\text { Percentage: } \\
100 \%\end{array}$ \\
\hline
\end{tabular}


Regarding the control group, it is noticeable that students performed less than those of the experimental group. More than half of the students got marks below 10 out of 20. Among 17 students, only five students (29.44\%) were able to get marks above the average. The highest percentage (23.52\%) goes for those students who got 7.5 out of 20 , and the lowest percentage $(5.88 \%)$ goes for those who got the marks: 4 ; $4.5 ; 5.5 ; 6 ; 8 ; 8.5 ; 10.5 ; 11 ; 12.5 ; 13 ; 13.5$. The highest mark in the control group is 13.5 and it was obtained by only one student $(5.88 \%)$.

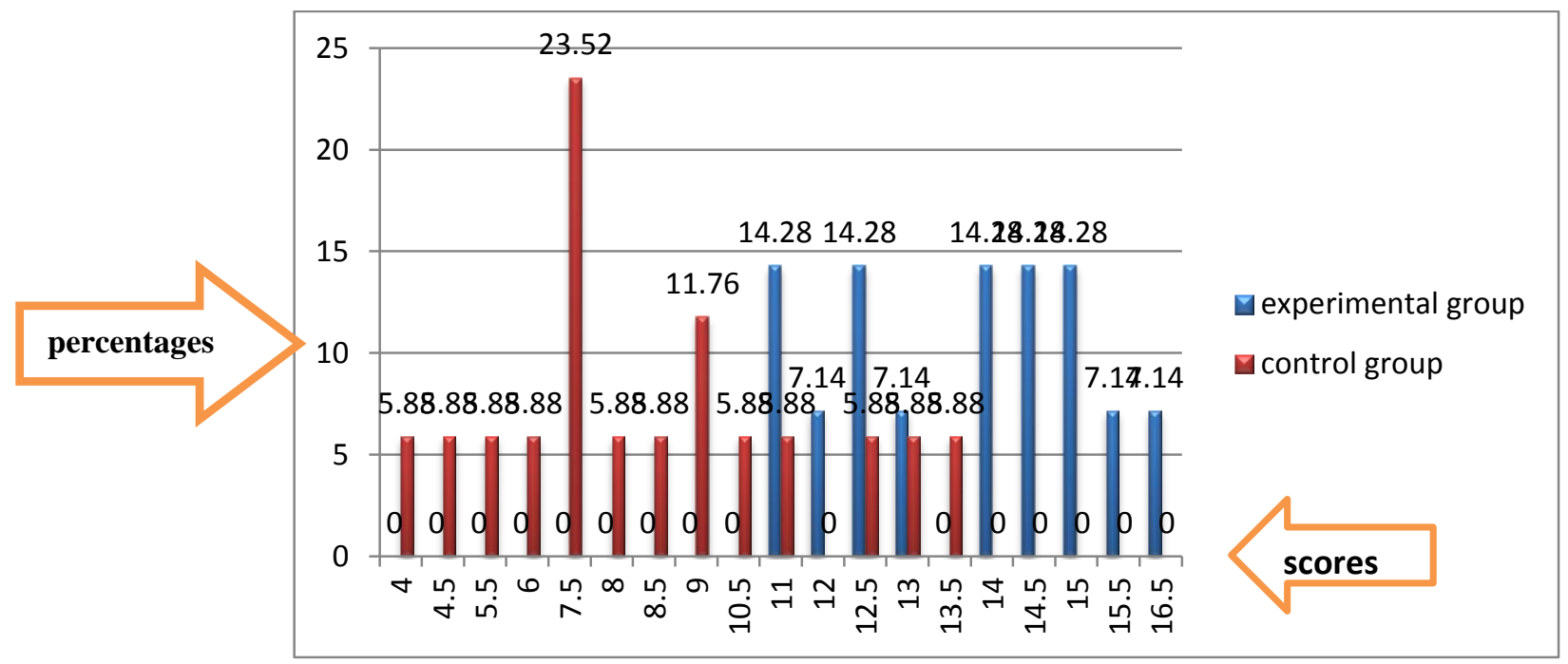

Figure 1: Brainstorming Test Results

\subsubsection{Results of the Predicting Test}

The data presented in Table 8 and Figure 2 show that all students (100\%) in the experimental group (B) were able to get scores above the average ranging from 11.5 to 19 out of 20 . The highest mark is 19 and it was obtained by only one student (6.66\%) while the lowest mark was 11.5 and $(20.01 \%)$ of students got it. Six students (39.99\%) were able to get very good marks ranging from 14 to 18 . Two students (13.33\%) got 13 and $(20.01 \%)$ of them got 13.5 out of 20 . 
Table 8: Predicting Test Results

\begin{tabular}{|c|c|c|c|c|c|c|}
\hline & & erimental G & $(\mathrm{B})$ & & Control Gi & \\
\hline & $\begin{array}{c}\text { Scores } \\
\text { (out of } \\
20)\end{array}$ & Frequency & Percentages & $\begin{array}{c}\text { Scores } \\
\text { (out of } \\
20 \text { ) } \\
\end{array}$ & Frequency & Percentages \\
\hline & 11.5 & 3 & $20,01 \%$ & 2.5 & 1 & $6,25 \%$ \\
\hline & 13 & 2 & $13,33 \%$ & 04 & 1 & $6,25 \%$ \\
\hline & 13.5 & 3 & $20,01 \%$ & 05 & 1 & $6,25 \%$ \\
\hline & 14 & 2 & $13,33 \%$ & 6.5 & 1 & $6,25 \%$ \\
\hline Post- & 15 & 2 & $13,33 \%$ & 07 & 1 & $6,25 \%$ \\
\hline & 18 & 2 & $13,33 \%$ & 8.5 & 1 & $6,25 \%$ \\
\hline & 19 & 1 & $6,66 \%$ & 9.5 & 1 & $6,25 \%$ \\
\hline & & & & 10 & 1 & $6,25 \%$ \\
\hline & & & & 10.5 & 1 & $6,25 \%$ \\
\hline & & & & 11.5 & 1 & $6,25 \%$ \\
\hline & & & & 12 & 1 & $6,25 \%$ \\
\hline & & & & 12.5 & 1 & $6,25 \%$ \\
\hline & & & & 13 & 1 & $6,25 \%$ \\
\hline & & & & 15.5 & 1 & $6,25 \%$ \\
\hline & & & & 16 & 1 & $6,25 \%$ \\
\hline & & & & 18.5 & 1 & $6,25 \%$ \\
\hline & $\begin{array}{c}\text { Average: } \\
14.26\end{array}$ & Total:15 & $\begin{array}{c}\text { Total } \\
\text { Percentage: } \\
100 \%\end{array}$ & $\begin{array}{c}\text { Average: } \\
10.15\end{array}$ & Total: 16 & $\begin{array}{c}\text { Total } \\
\text { Percentage: } \\
100 \% \\
\end{array}$ \\
\hline
\end{tabular}

In the control group, the average (10.15) was less than the average obtained by the experimental group (14.26). The highest mark is 18.5 out of 20 and it was obtained by one student $(6.25 \%)$ while the lowest mark is 2.5 out of 20 and it was also obtained by one student $(6.25 \%)$. There are seven students $(43.75 \%)$ 
who obtained marks below the average ranging from 2.5 to 9.5 out of 20 . Nine students $(56.25 \%)$ obtained marks above the average ranging from 10 to 18.5 out of 20 .

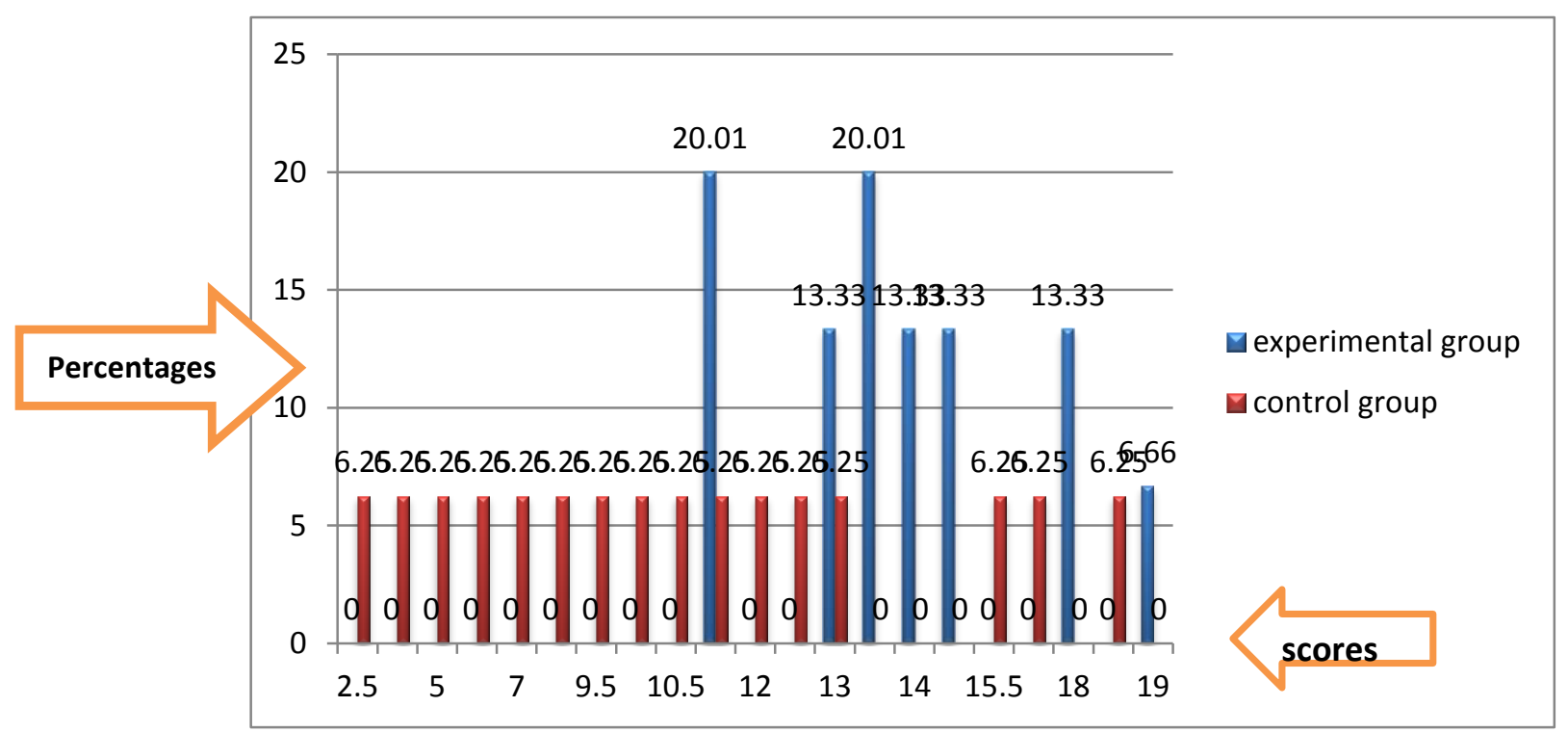

Figure 2: Predicting Test Results

The following table (Table 9) presents the participants' results in the pre- and post-tests along with the scores obtained by each participant so that performances under the two conditions can be easily compared. 
Table 9: The Participants' Scores in the pre- and post-tests (Experimental Groups A \& B)

\begin{tabular}{|c|c|c|c|c|c|}
\hline \multicolumn{3}{|c|}{ Experimental Group 'A' } & \multicolumn{3}{|c|}{ Experimental Group 'B' } \\
\hline $\begin{array}{l}\text { Scores in } \\
\text { the Pre- } \\
\text { test (out } \\
\text { of 20) }\end{array}$ & $\begin{array}{l}\text { Scores in the } \\
\text { Post-test (out } \\
\text { of } 20 \text { ) }\end{array}$ & $\begin{array}{c}\text { Improvemen } \\
\mathrm{t}\end{array}$ & $\begin{array}{l}\text { Scores in } \\
\text { Pre-test (out } \\
\text { of 20) }\end{array}$ & $\begin{array}{l}\text { Scores in the } \\
\text { Post-test (out of } \\
\text { 20) }\end{array}$ & Improvement \\
\hline 00 & 12 & 12 & 02 & 11.5 & 9.5 \\
\hline 00 & 12.5 & 12.5 & 04 & 13 & 09 \\
\hline 04 & 11 & 07 & 04 & 13.5 & 9.5 \\
\hline 04 & 11 & 07 & 04 & 18 & 14 \\
\hline 06 & 15 & 09 & 04 & 18 & 14 \\
\hline 06 & 15.5 & 9.5 & 04 & 14 & 10 \\
\hline 06 & 12.5 & 6.5 & 04 & 13.5 & 9.5 \\
\hline 06 & 14 & 08 & 04 & 19 & 15 \\
\hline 08 & 16.5 & 8.5 & 04 & 13.5 & 9.5 \\
\hline 08 & 13 & 05 & 06 & 11.5 & 11.5 \\
\hline 08 & 15 & 07 & 06 & 15 & 09 \\
\hline 08 & 14 & 06 & 06 & 11.5 & 5.5 \\
\hline 08 & 14.5 & 6.5 & 06 & 15 & 09 \\
\hline 10 & 14.5 & 4.5 & 08 & 14 & 06 \\
\hline & & & 08 & 13.5 & 5.5 \\
\hline $\begin{array}{c}\text { Average: } \\
5.85\end{array}$ & $\begin{array}{c}\text { Average: } \\
13.64\end{array}$ & $\begin{array}{c}\text { Difference: } \\
+7.79\end{array}$ & $\begin{array}{c}\text { Average: } \\
4.93\end{array}$ & $\begin{array}{c}\text { Average: } \\
14.3 \\
\end{array}$ & $\begin{array}{c}\text { Difference: } \\
+9.37\end{array}$ \\
\hline
\end{tabular}

\section{Discussion}

This study aimed at investigating the effects of schema activation on EFL students' reading comprehension. The results of the students' questionnaire and the experimental tasks demonstrated that prior knowledge activation had positive effects on students' reading comprehension and supported other 
researchers' claims that the comprehension process occurs when there is an interaction between the text being read and the readers' previously stored information (e.g. Carrell \& Eisterhold 1983; Anderson, 1985; Anderson \& Pearson, 1988). In more details, the results of the last section of the questionnaire (schema activation and reading comprehension) and the difference between the scores obtained by both experimental groups (A \& B) and those of the control group (C) in the post-test indicate that schema acts as a basis on which students can build new knowledge and helps them connect what they are reading to what they already know. Therefore, better comprehension of the text will be achieved (Carrell \& Eisterhold, 1983; Anderson, 1985 as cited in McCormack \& Pasquarelli, 2009; Probst, 1987; Anderson \& Pearson, 1988).

As for schema activation strategies, the results of the study revealed that the experimental group (A) showed better performance in the post-test as opposed to the students of the control group (C) who were not taught how to use brainstorming as a schema activation strategy. In other words, the scores obtained by the experimental group demonstrated that brainstorming is an effective strategy that enhances the activation of readers' schemata. It provides them with a chance to tap into their previous knowledge and make connections between what is new and what they already know (Feather 2004 as cited in Ghabanchi \& Behrooznia, 2014).

Regarding the second experimental group (B), the results were also positive when compared with the results of the control group (C). This is because, unlike group (C), in group (B), students' prior knowledge was activated through making predictions about the content of the text before reading it. This leads us to conclude that predicting, as a schema activation strategy, is of great importance in the process of comprehending a given piece of writing. It gets the learners think about the ideas that may occur throughout the text before reading it (Ajideh, 2006). By doing so, learners make connection between the new input and their existing knowledge (Gillet \& Temple, 1982 as cited in Kelly \& Clausen-Grace, 2007). Thus, they become more engaged in reading and motivated since they feel the necessity to find out what happens in the text (Paris et al., 1991 as cited in Wood, 2008).

\section{Conclusion, Implications and Limitations}

Our study took place in the department of English at Blida 2 University, Algeria. Its main focus was on the effects of two schema activation strategies, namely brainstorming and predicting, on first year LMD students' reading comprehension. To this end, two research instruments were used: a questionnaire and reading comprehension tests. The results of the questionnaire revealed that activating schema prior to reading is strongly needed in order to help students construct the meaning of a given text. In addition, the results of the experiment showed that the two experimental groups (Groups 'A' and 'B') performed better than the control group (Group ' $C$ ') in terms of text comprehension. This implies that the training sessions, using brainstorming and predicting as schema activation strategies, had considerable effects on students' scores and increased the level of comprehension. This leads us to conclude that prior knowledge is the basis of text comprehension and that the closer the match between the reader's schema and the text, the more comprehension occurs. 
In light of the study's results, some pedagogical implications are offered. To begin with, due to the fact that group work increases students' motivation to learn, having students working together to brainstorm ideas about a given topic and predict the content of the text before reading has several advantages. First, it encourages students to listen, communicate and consider others' ideas. Moreover, brainstorming and predicting in groups results in students sharing their previous experiences with each other. Hence, more ideas about the topic of the text are generated and, thus, the chances for deeper comprehension are increased. Second, teachers of reading are recommended to encourage their students to use think aloud strategy when brainstorming and predicting because this strategy can lead to more strategic reading and allow students to see the different steps of using a particular strategy (brainstorming or predicting). Besides, think aloud strategy improves the classroom environment in terms of interaction and involvement in the learning process. More importantly, this strategy causes the reader to monitor his/her comprehension through interaction with the reader's own thoughts and those of others while reading. Therefore, students will better comprehend what they read (Duke \& Pearson, 2002 as cited in Wood, 2008).

However, this study is not without limitations. The first limitation is time constraint as we did not have enough time to test other schema activation strategies. Rather, only two strategies, brainstorming and predicting, were tested. The second limitation is concerned with the number of participants ( 47 students). The results could not be generalized to a larger population. We believe that a study with a larger sample could have had more convincing and reliable results. Thus, further research needs to be done to examine the results of this study and test other schema activation strategies with a larger population including second and third levels.

\section{Acknowledgement}

Sincere appreciation is expressed to Professor Faiza Bensemmane from Algiers 2 University - Algeria for her valuable comments and suggestions to improve this paper.

\section{References}

Ajideh, P. (2006). Schema theory-based considerations on pre-reading activities of ESP textbooks. The Asian EFL Journal, 16, 1-19

Alqahtani, A.A., \& Aljidy, A.B. (2011). Reading texts in translation classes: discourse analysis perspectives. Theory and Practice in Language Studies. 1(11), 1507-1513.

Anderson, R.C., \& Pearson, D. P. (1988). A schema-theoretic view of basic processes in reading comprehension. In Carrell, P.L \& Devine, J \& Eskey, D.E. Interactive approaches to second language reading. pp. 37-53. Cambridge: Cambridge University Press.

Bartlett, F. (1932). Remembering: a study in experimental and social psychology. Cambridge: Cambridge University Press.

Carrell, P.L., \& Eisterhold, J.C. (1983). Schema theory and EFL reading pedagogy. TESOL Quarterly, 17 (4), 353-373.

Dechant, E. (2013). Understanding and Teaching Reading: An Interactive Model. New Jersey: Lawrence Erlbaum Associates.

Dorn, L. J., \& Soffos. C. (2005). Teaching for deep comprehension: a reading workshop approach. Portland, Maine: Stenhouse Publishers. 
Ghabanchi, Z., \& Behrooznia, S. (2014). The impact of brainstorming on reading comprehension and critical thinking ability of EFL learners. Procedia - Social and Behavioral Sciences, 98, 513-521.

Goodman, K.S. (1976). Reading: a psycholinguistic guessing game. Journal of the Reading Specialist, 6(4), 126-135.

Grabe, W., \& Stoller, F. (2001). Reading for academic purposes: guidelines for the ESL/EFL teacher. In Celce-Murcia, M (ed.). Teaching English as second or foreign language, pp. 187-204. USA: Heinle $\&$ Heinle.

Kelly, M., \& Clausen-Grace, N. (2007). Comprehension shouldn't be silent: from strategy instruction to student independence. International Reading Association. Inc.

Kirk, S.J., \& Spreckelmeyer, K.F. (1993). Enhancing Value in Design Decisions. Michigan: University of Michigan.

Küçükoğlu, H. (2012). Improving reading skills through effective reading strategies. Procedia Social and Behavioral Sciences, 70, 709-714.

McCormack, R.L., \& Pasquarelli, S.L. (2010). Teaching Reading Strategies and Resources for Grades K6. New York: The Guilford press.

Olshavsky, J.E., \& Kletzing, K. (1979). Prediction: one reading strategy for reading success in high school. Journal of Reading, 22(6), 512-516.

Probst, R.E. (1987). Transactional theory in the teaching of literature. ERIC Clearinghouse on Reading and Communication Skills Urbana IL. Retrieved December 27 $7^{\text {th }}, 2017$ from: https://www.ericdigests.org/pre-926/theory.htm

Rumelhart, D.E. (1980). Schemata: the building blocks of cognition. In Spiro, R.J., Bruce, B.C \& Brewer, W. F (eds) Theoretical issues in reading comprehension, Lawrence Erlbaum Associates.

Wallace, C. (2003). Critical reading in language education. UK: Palgrave Macmillan

Wood, O. L. (2008). An Evaluation of the effectiveness of the reading strategy sketch to stretch on the 9th grade reading texts assessment of knowledge and skills test. Unpublished MA thesis, University of Texas at El Paso.

Wyse, D., \& Goswami, U. (2012). Early reading development. In Larson, J. and Marsh, J. The SAGE handbook of early childhood literacy. Los Angeles: SAGE. 